УДК 621.396:61

\title{
АЛГОРИТМ РАСЧЕТА ОПТИМАЛЬНЫХ ЗНАЧЕНИЙ ВЕСОВЫХ КОЭФФИЦИЕНТОВ ДЛЯ КОГЕРЕНТНОГО НАКОПЛЕНИЯ ОТРАЖЕНИЙ
}

\author{
РЫСАКОВ Н. Д., КУЦЕНКО В. В.
}

Харьковский университет Воздушных Сил, Украина, Харьков, 61023, ул. Сумская 77/79

\begin{abstract}
Аннотация. Предложена расчетная формула оптимальных значений весовых коэффициентов когерентного накопления отражений для минимизации уровня боковых лепестков амплитудно-фазовых характеристик (АФХ) доплеровских фильтров для любого их числа. Рассчитаны и приведены графики АФХ доплеровских фильтров для когерентного накопителя из $8,12,16,24,32$ и 36 фильтров. Оценен средний уровень боковых лепестков, свидетельствующий о достоверности предложений
\end{abstract}

Ключевые слова: весовой коэффициент; доплеровский фильтр; фильтрация; амплитудно-фазовая характеристика; боковой лепесток

\section{1. ВСТУПЛЕНИЕ}

Сложность реализации моноимпульсных способов пеленгации самолета на заключительном этапе посадки при плохой видимости взлетно-посадочной полосы (ВПП) состоит в сильном влиянии на точность пеленгации как отражений от земной поверхности, так и от метеооблаков. Компенсация такого влияния в моноимпульсной радиолокационной станции (МРЛС) автосопровождения посадки самолета является проблемной задачей.

В [1] проанализирована возможность реализации моноимпульсных каналов пеленгации самолета в плоскостях курса и угла места двумя способами в предположении, что проблема компенсации мешающего влияния пассивных помех (ПП) решена. В [2] предложены значения коэффициентов сглаживания боковых лепестков амплитудно-фазовых характеристик 16 доплеровских фильтров.
В данной работе предлагается расчетная формула оптимальных значений весовых коэффициентов накопления отраженных импульсов для минимизации уровней боковых лепестков амплитудно-фазовых характеристик доплеровских фильтров для любого их числа.

\section{2. ОСНОВНАЯ ЧАСТЬ}

Преимущества моноимпульсных способов определения угловых координат цели обуславливают целесообразность их реализации для обеспечения управления посадкой самолета в условиях плохой видимости ВПП. При этом компенсировать мешающее влияние ПП возможно путем доплеровской фильтрации отражений в МРЛС автосопровождения отдельного самолета.

Эффективность обычной доплеровской фильтрации отражений в обзорных РЛС ограничивается двумя факторами: 